\title{
Solving the problem of logistics center location based on the AHP method
}

\author{
Sabina Kauf ${ }^{1}$, AgnieszkaTtuczak $^{2, *}$ \\ ${ }^{1}$ Opole University, Faculty of Economics, Ozimska str. 46a, 45-058 Opole \\ ${ }^{2}$ Opole University, Faculty of Economics, Ozimska str. 46a, 45-058 Opole
}

\begin{abstract}
The aim of this paper is to present the method of locating logistic centres in a regular hierarchical logistics network. The problem is to determine the optimal location of logistic centres with given selection criteria. Among many methods, the authors will decide on the use of the AHP method, which is an effective tool for selecting a location.
\end{abstract}

\section{Introduction}

Logistics centers are an important part of the infrastructure of each country. They are an important factor of economic development, they influence on the flow of goods and they contribute to the increase of efficiency of supply chains. Global forecasts indicate that logistics centers, both industry, local, regional and international, determine global supply networks. This role is attributed to distribution centers, warehousing and distribution centers, trans-shipment terminals, central warehouses, warehouse bases or logistics platforms. Their aim is to create added value in the flow of goods, to alleviate or eliminate the nuisance of environmental logistic activities, as well as to support and initiate desired directions of business development, mainly in the area of logistics $[1,2]$.

Although the first centers were created more than thirty years ago, commonly accepted definition has not been developed to this day. This is due to the lack of absence of standard methodologies or decision criteria [3]. However, without going into a wider definition discourse (overview of ways of defining the logistics center are presented by Higgins, Ferguson and Kanaroglou [4]), we appeal only to the recognition of logistic centers in the infrastructural context, i.e. as transhipment points and intermodal terminals with the highest degree of complexity in which they combine streams of cargoes flowing through global supply chains. In this way, centers define, among others Tsamboulas and Dimitropoulos (1999) and Winkler and Seebacher (2011): "logistic interconnection points in a local and long-distance goods transport" $[5,6,7,8]$.

The construction of a logistics center is a strategic decision, mainly due to the irreversible effects resulting from the choice of location. This indicates the particular importance of the localization problem $[9,10]$. Decisions in this respect are made in relation to a specific economic and spatial system, which creates specific consequences for actions aimed at the optimal deployment of newly planned facilities. Depending on the nature of the localized center and the type of logistics network to be part of, there is a different degree of complexity of the location problem $[11,12,13]$. As a consequence, various mathematical methods and formulas can be used to solve the problem. Bearing in mind the importance of the problem of the center's location and the multiplicity of possible methods in this study, the AHP method was presented to determine the location of the logistics center $[14,15,16,17]$.

\section{Literature review}

In the literature, a lot of space is devoted to the methods of location of logistic objects in a logistics network (including Owen, Daskin, 1998; Özcan, Celebi, Esnaf 2011; Van Thai, Grewal, 2005; Drezner, Hamacher, 2002; Church, Murray, 2009 Farahani, Hekmatfar 2009, Farahani, SteadiSeifi MS, Asgari 2010 [2, 18, 19, 20, 21, $22,23,24])$. The classification of localization problems according to the criterion function, decision variables and system parameters is also considered. When solving the problem of object location in the network, various aspects should be taken into account, including its structure and forms of object connections. In this case, the problem is searching for answers, among others for questions such as: is each node assigned to one or many objects, is the connection node - node with the omission of the logistic object acceptable and whether the connection object object are full or partial?

Choosing the right location of a logistics center is not easy [25]. It is usually taken after taking into account many criteria, such as: (1) technical (usable) - including road density indicator, efficient telecommunications network, number of potential contractors, storage infrastructure, intellectual resources; (2) economic - capital expenditures, annual operating costs, cost measures (eg. the cost of moving a unit of cargo) indicator of

\footnotetext{
* Corresponding author: atluczak@uni.opole.pl
} 
development trends, share of international turnover, (3) hard to measure, including reliability, flexibility, expandability [26]. Brenke, based on research carried out in 2000, established the following hierarchy of location factors: (1) proximity to markets, (2) labor costs, (3) supply of qualified labor, (4) business support measures, (5) proximity to the motorway, (6 ) energy costs, (7) proximity to suppliers [27]. Mentzer (2008) points to three basic economic factors determining location decisions: land, labor and capital [28], and Mindur as criteria for the location of logistics centers, taking into account the possibility of adapting existing logistics infrastructure, proposes, among others [29] (1) the possibility and cost of buying land for the investment, (2) the cost of land treatment, (3) connection to the existing railway network, (4) the cost of building additional warehouses or office facilities, (5) the cost of building parking and parking yards, (6) the cost of supplying new facilities in the media, (7) the cost of preparing technical documentation [29]. The presented criteria show that searching for the location of a logistic center is usually reduced to determining the lowest costs, taking into account many places of obtaining raw materials and distribution places for finished products [26, 28, 29]. And that means the primacy of economic factors [1]. This fact was already cited in 1929 by Weber (1929) [26], writing: "[...] uses and simple set-kilometers to optimize the location and set of customers".

Location problems can be solved using various methods that can be classified according to $[20,30]$ :

- approaches to formulating the problem - mathematics rankings and programming, optimization problems; number of assessment criteria - simple, multi-criteria;

- approaches to risk management and its division mathematical, expert estimates;

- topographic nature of the network - continuous and discrete location problems;

- number of objects to be considered for the location one or many objects.

Farahani, SteadiSeifi and Asgari (2010) provide an overview of localization problems formulated as problems with multi-criteria decisions [20]. Klose and Drexl, on the other hand, focus on optimization methods, using mathematical programming [30, 31]. Daskin (1995) presented the method of distance minimization, also called the gravitational method [18]. To evaluate the location methods are used descriptive and analytical and descriptive, not requiring knowledge of the sophisticated mathematical methods. An interesting approach to solving the problem of the location of logistic facilities is to look for a variant of the number and location of these objects, for which the sum of transport and storage costs is minimal [25]. Noteworthy are also methods of linear optimization, static one-criterion methods with analytical and numerical implementation [27]. The multi-criteria optimization methods, e.g. AHP, TOPSIS, are also used to solve the problem of warehouse locations.

\section{AHP method}

Considering several potential locations of the warehouse, the decision maker is the most convenient to choose localization. During the analysis of individual variants, it may be guided by criteria depending on its individual preferences. In such situations, it is advisable to use multicriteria analysis methods such as AHP. The AHP method has gained wide recognition in decision-making processes. Literature analysis points to several hundred articles using AHP / ANP methods in various fields and is used in many countries, e.g. in the United States, Turkey, China, Japan, Brazil, the Czech Republic and Poland, where it gains more and more supporters. In the area of transport, this method was used to assess transport systems [32, 33, 34], evaluation of the railway corridor in Memphis [35], analysis of multi-criteria problems in road transport [36], telematics technologies in the management of a fleet of hazardous materials [37, 38] and reverse logistics $[39,40]$. Evaluation of large investment projects, evaluation of alternative fuels, selection of optimal transport policy reducing impact on climate change. These are just a few of the many uses of this method. The authors cite the following example of the use of AHP from the article by M. Berrittell, A. Certa, M. Enea and P. Zito "An Analytic Hierarchy process for the evaluation of transport policies to reduce climate change impacts" [41]. Analytic Hierarchy Process (AHP) is a commonly accepted and used tool for making complex decisions based on a large number of criteria. The basis of AHP is the hierarchical decomposition of the assessment criteria. The hierarchy of validity in the AHP method has a predetermined structure. First, the purpose of the decision-making process is chosen, then the evaluation criteria and the solution variants are set [41, 42, 43, 44]. In AHP, the decision maker has an impact on the entire process - AHP is a method that allows you to choose the best solution from among many variants. The decisionmaker assesses possible variants of choice in terms of specific criteria for the possibility of assessing the value of these criteria in terms of the objective according to their knowledge and experience-based recognition [5, 42, 45]. The use of the AHP method follows the following steps: 1. Construction of a pairwise comparison matrix for all criteria in pairs and matrices enabling the comparison of potential locations in pairs in relation to all criteria. Assessment criteria by pair comparison is made by the decision maker according to the scheme $[5,45,46]$ :

1 - equal importance (both factors contribute equally to achieving the goal);

3 - a small advantage (judgments and experience slightly prefer one factor over another);

5 - strong advantage (judgment and strong experience put one factor above the other);

7 - very strong advantage (one factor is strongly put above the other, practice confirms this);

9 - absolute advantage (the advantage of one factor over the other is absolute and confirmed in the highest degree). Intermediate values 2, 4, 6 and 8 are assigned in the case of difficulty in the classification of the result and when we think that it lies between the characteristics specified in the classification [47, 48, 49]. 
This step completes the formation of a matrix $A=\left[a_{i j}\right]_{n \times n}$, there is a $\frac{n(n-1)}{2}$ in possibility of comparisons. Characteristic for these matrices is that $\mathrm{a}_{\mathrm{ii}}=1$ and $[17,18$, $19,28,29,33,50,51]$ :

$$
a_{j i}=\frac{1}{a_{i j}} \mathrm{i} \neq \mathrm{j}, \mathrm{i}, \mathrm{j}=1,2, \ldots, \mathrm{n}
$$

The next step of the AHP method is the normalization of matrix elements $\mathrm{A}=\left[\mathrm{a}_{\mathrm{ij}}\right]$ according to the formula $[5,40$, 41, 45, 46, 47]:

$$
\hat{a}_{i j}=\frac{a_{i j}}{\sum_{i=1}^{n} a_{i j}}, \mathrm{j}=1,2, \ldots, \mathrm{n}
$$

Based on the normalized matrix elements the individual preferences indexes are determined referred (forming a column vector $\mathbf{C}=\left[\mathrm{c}_{\mathrm{i}}\right](i=1,2, \ldots, n)$ according to the formula $[41,43,51]$ :

$$
c_{i}=\frac{\sum_{j=1}^{n} \widehat{a_{l j}}}{n}(i=1,2, \ldots, n)
$$

which indicate the place of the $i^{\text {th }}$ variant in the ranking the higher the value, the higher the ranking. The individual ranking for criteria is determined in the same way.

The final step of the presented method is the determination of vector $\mathrm{C}=\left[\mathrm{c}_{\mathrm{i}}\right](\mathrm{i}=1,2, \ldots, \mathrm{m})$, multicriteria preference indexes, whose coordinates are calculated according to the formula $[41,42,51]$ :

$$
c_{i}=\sum_{k=1}^{n} c_{k} c_{i}
$$

The $c_{i}$ values determine the position of $i$-th variant in ranking (the higher the value, the higher the rank).

When many pairwise comparisons are performed, some inconsistencies may typically arise.

Analysis of matrix consistency is made through appropriate transformations of the matrix's own vectors $[43,48,49,52]$, thus calculating the Consistency Ratio (CR) according to formula (2):

$$
C R=\frac{\lambda_{\max }-n}{r(n-1)}
$$

where: $\lambda_{\max }$ - maximum value of the own vector of the preference matrix of $n, n$ - number of compared characteristics. It is assumed that the coefficient of consistency is accepted (comparison of characteristics is consistent) when the $\mathrm{CR}$ value is less than or equal to $10 \%$. Then rankings of particular characteristics are calculated for the first and subsequent criteria respectively. Subsequently, rankings for variants (subcriteria) are calculated.

\section{Application the AHP method in solving the problem of the location of a logistics center}

The first step, regardless of the chosen method, is the analysis of various conditions related to a given investment process and participating in it entities, aimed at indicating appropriate variants and decision-making factors. Catalog of example criteria and sub-criteria, determining the implementation of the localization of warehouse, has been presented in figure 1 . It should be noted that these factors are only of a nature exemplary, developed on the basis of selected thematic publications. In a real situation, the choice of individual factors should be justified by the results of relevant analyzes (including applicable legal regulations) made by an expert group. It is worth noting that the accuracy of the work analytical results translate into the reliability of results obtained by the AHP method.

Due to the theoretical nature of the problem decision, only selected elements of the AHP algorithm are indicated. The choice of location should start with the construction of a hierarchical decision model (Fig.1).

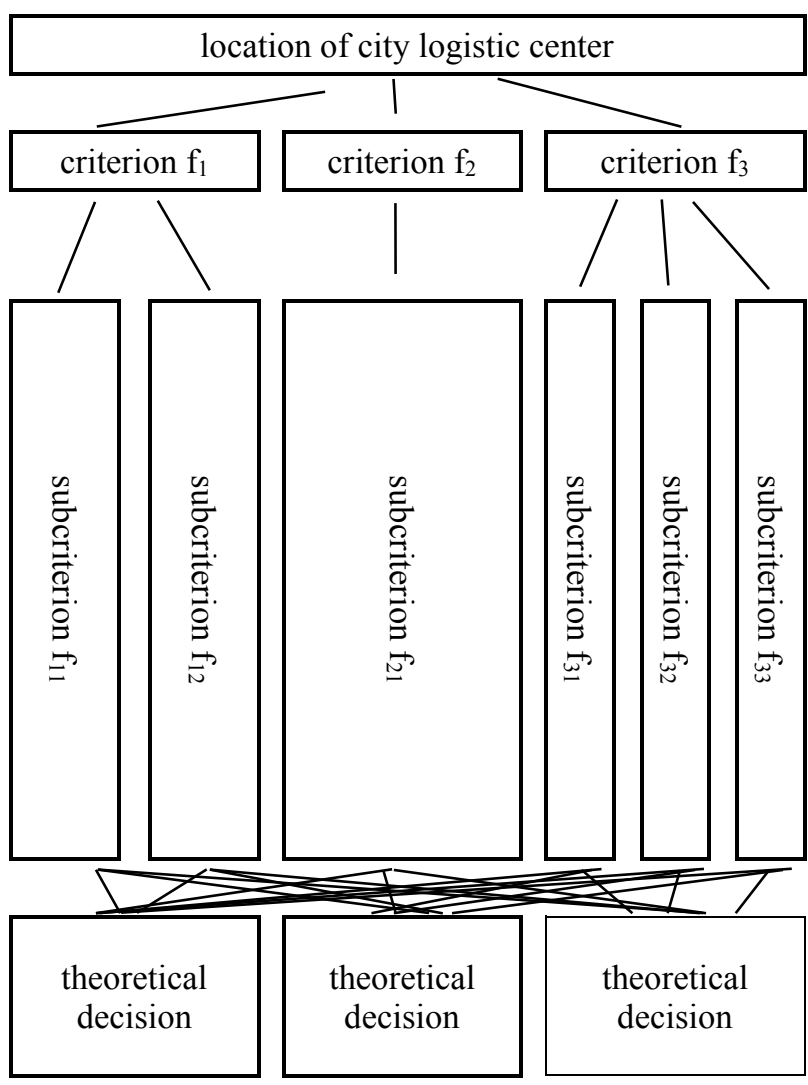

Fig. 1. Hierarchical model (decomposition of the decision problem)

Suppose we are considering a discrete problem of multicriteria decision making, in which six decision-making variants are assessed on the basis of three criteria. The first two criteria are unmeasurable, while the third, maximized criterion is known to the decision-maker as real numbers (tab. 1). At the beginning the pairwise comparison matrix should be determined (tab. 2). Using the Saaty method, the c scale vector is as follow $(0.076 ; 0.657 ; 0.267)$

Table 1.Value of criterion $\mathrm{f}_{3}$ 


\begin{tabular}{|l|l|l|l|l|l|l|}
\hline & $\mathbf{a}^{1}$ & $\mathbf{a}^{2}$ & $\mathbf{a}^{3}$ & $\mathbf{a}^{4}$ & $\mathbf{a}^{5}$ & $\mathbf{a}^{6}$ \\
\hline$f_{3}\left(\mathbf{a}^{\mathbf{i}}\right)$ & 19 & 35 & 24 & 29 & 24 & 28 \\
\hline
\end{tabular}

Table 2. The pairwise comparison matrix

\begin{tabular}{|c|c|c|c|}
\hline & $f_{1}$ & $f_{2}$ & $f_{3}$ \\
\hline$f_{1}$ & 1,000 & 0,143 & 0,333 \\
\hline$f_{2}$ & 5,000 & 1,000 & 7,000 \\
\hline$f_{3}$ & 5,000 & 0,333 & 1,000 \\
\hline$s_{j}$ & 11,00 & 1,48 & 8,33 \\
\hline
\end{tabular}

In the end of first step of the AHP method the "own value" or "characteristic value" of matrix should be found, in this research it is $\lambda_{\max }=3,690$. The value of the modified CR consistency measure will be calculated according to formula 5 , and it is equal $\mathrm{CR}=0,595$, which indicates the existence of sufficient consistency of assessments.

Next the decisions-maker has to compare of individuals decision-making variants with respect to each criterion $f_{1}$ and $f_{2}$. Using the Saaty method, standardized matrices of variants were created (tab. 3, tab. 5), relative to the first and second criteria $f_{1} \mathrm{i}_{2}$ on the basis of which the $\mathrm{c}_{1}$ and $\mathrm{a} \mathrm{c}_{2}$ scale vectors were found (tab. 4).

Table 3. Normalized matrix for criterion $f_{1}$

\begin{tabular}{|c|c|c|c|c|c|c|}
\hline & $\mathbf{a}^{1}$ & $\mathbf{a}^{2}$ & $\mathbf{a}^{3}$ & $\mathbf{a}^{4}$ & $\mathbf{a}^{5}$ & $\mathbf{a}^{6}$ \\
\hline $\mathbf{a}^{1}$ & 0,548 & 0,459 & 0,404 & 0,329 & 0,283 & 0,250 \\
\hline $\mathbf{a}^{2}$ & 0,078 & 0,153 & 0,173 & 0,164 & 0,189 & 0,286 \\
\hline $\mathbf{a}^{3}$ & 0,061 & 0,031 & 0,058 & 0,066 & 0,047 & 0,179 \\
\hline $\mathbf{a}^{4}$ & 0,183 & 0,306 & 0,288 & 0,329 & 0,425 & 0,143 \\
\hline $\mathbf{a}^{5}$ & 0,069 & 0,031 & 0,058 & 0,066 & 0,047 & 0,107 \\
\hline $\mathbf{a}^{6}$ & 0,061 & 0,022 & 0,019 & 0,047 & 0,009 & 0,036 \\
\hline
\end{tabular}

The values of the modified consistency measure CR for the comparison of options with respect to the first criterion $f_{1}$ is 0.003 , while for the second criterion $f_{2}$ it is 0.228 . This indicates that there is sufficient consistency of assessments. Due to the fact that the value of the third criterion $f_{3}$ are real numbers, the scale vector $c_{3}$ was determined as the normalized values of the third criterion in table 6.

In next step C matrix was determined, columns in this matrix are scale vectors for all criteria. The $\mathrm{C}$ matrix is presented in table 7.

The product of the matrix $\mathrm{C}$ and the vector of the scale $\mathrm{c}$ (formula 4) forms the final vector of the scale $\mathrm{c}$ on the basis of which the ranking of decision variants was created. The ranking of variants is as follow: $a_{3}=0,063$; $a_{5}=0,076 ; a_{2}=0,134 ; a_{4}=0,172 ; a_{1}=0,260 ; a_{6}=0,295$.

Table 4. Scale vectors $c_{1}, c_{2}$

\begin{tabular}{|l|l|l|l|l|l|l|}
\hline $\mathbf{c}_{1}$ & 0,379 & 0,174 & 0,073 & 0,279 & 0,063 & 0,032 \\
\hline
\end{tabular}

\begin{tabular}{|l|l|l|l|l|l|l|}
\hline $\mathbf{c}_{2}$ & 0,304 & 0,094 & 0,025 & 0,156 & 0,047 & 0,373 \\
\hline
\end{tabular}

Table 5. Normalized matrix for criterion $\mathrm{f}_{2}$

\begin{tabular}{|c|c|c|c|c|c|c|}
\hline & $\mathbf{a}^{1}$ & $\mathbf{a}^{2}$ & $\mathbf{a}^{3}$ & $\mathbf{a}^{4}$ & $\mathbf{a}^{5}$ & $\mathbf{a}^{6}$ \\
\hline $\mathbf{a}^{1}$ & 0,168 & 0,271 & 0,300 & 0,517 & 0,356 & 0,210 \\
\hline $\mathbf{a}^{2}$ & 0,056 & 0,054 & 0,100 & 0,034 & 0,238 & 0,084 \\
\hline $\mathbf{a}^{3}$ & 0,024 & 0,011 & 0,033 & 0,015 & 0,010 & 0,060 \\
\hline $\mathbf{a}^{4}$ & 0,056 & 0,271 & 0,167 & 0,103 & 0,198 & 0,140 \\
\hline $\mathbf{a}^{5}$ & 0,024 & 0,014 & 0,100 & 0,021 & 0,040 & 0,084 \\
\hline $\mathbf{a}^{6}$ & 0,672 & 0,379 & 0,300 & 0,310 & 0,158 & 0,421 \\
\hline
\end{tabular}

Table 6. Normalized value of criterion $f_{3}$, scale vector $\mathbf{c}_{3}$

\begin{tabular}{|c|c|c|}
\hline & $f_{3}\left(\mathbf{a}^{\mathbf{i}}\right)$ & $\mathbf{c}_{3}$ \\
\hline $\mathbf{a}^{1}$ & 19 & 0,119 \\
\hline $\mathbf{a}^{2}$ & 35 & 0,220 \\
\hline $\mathbf{a}^{3}$ & 24 & 0,151 \\
\hline $\mathbf{a}^{4}$ & 29 & 0,182 \\
\hline $\mathbf{a}^{5}$ & 24 & 0,151 \\
\hline $\mathbf{a}^{6}$ & 28 & 0,176 \\
\hline
\end{tabular}

Table 7. C matrix - scale vectors for all criteria

\begin{tabular}{|c|c|c|c|}
\hline & $\mathbf{c}_{1}$ & $\mathbf{c}_{2}$ & $\mathbf{c}_{3}$ \\
\hline $\mathbf{a}^{1}$ & 0,379 & 0,304 & 0,119 \\
\hline $\mathbf{a}^{2}$ & 0,174 & 0,094 & 0,220 \\
\hline $\mathbf{a}^{3}$ & 0,073 & 0,025 & 0,151 \\
\hline $\mathbf{a}^{4}$ & 0,279 & 0,156 & 0,182 \\
\hline $\mathbf{a}^{5}$ & 0,063 & 0,047 & 0,151 \\
\hline $\mathbf{a}^{6}$ & 0,032 & 0,373 & 0,176 \\
\hline
\end{tabular}

\section{Conclusion}

The construction of logistic centers is a big financial challenge and creates a lot of problems, like most business-investments construction. However, correctly located on the basis of preliminary research and simulations, it can certainly be a source of income not only in financial terms but also in terms of environmental protection.

Activities related to the location of logistic centers and their very construction should be implemented at a priority pace. Summing up, the location, of such a huge undertaking as, the logistics center should be preceded by a series of detailed studies and simulations that would clearly indicate and justify the construction of such a facility. 
Among many methods that can help in choosing the right location, the AHP method should be indicated. Based on the research presented in this article, it can be concluded that AHP method is proper to choose location for logistics center. The analyzes carried out were aimed at selecting, from the point of view of commercial activities, the location of a new logistics center. The proposed procedure of selecting a location allows to meet the criterion of transport accessibility and equal attractiveness for as many potential clients as possible.

\section{References}

1. F. Chen, Z. Drezner, J. K. Ryan, Simchi-Levi D., Quantifying the Bullwhip Effect in a Simple Supply Chain: The Impact of Rorecasting, Lead Times, and Information. "Management Science", Vol. 46, No 3, (2000)

2. R.L. Church, A.T. Murray, Business Site Selection, Location Analysis and GIS, John Wiley and Sons, New York (2009)

3. D. A. Tsamboulas, I. Dimitropoulos, Appraisal of investments in European nodal centres for goods freight villages: A comparative analysis, Transportation 26(4):381-398 (1999)

4. C. D. Higgins, M. Ferguson P. S. Kanaroglou, Varieties of logistics centres: developing a standardized typology and hierarchy, The Transportation Research Board Volume 2288 (2012)

5. S. Kauf, A. Tłuczak, Optimization of logistics decisions (Optymalizacja decyzji logistycznych), Warszawa, Difin, 30-50 (2016)

6. H. Winkler, G. Seebacher, Management of freight villages: findings from an exploratory study in Germany, International Journal of Logistics: Research and Applications, Vol. 14, No. 4, pp. 271-283 (2011)

7. C. Rao, M. Goh, Y. Zhao, J. Zheng, Location selection of citylogistics centers under sustainability, Transportation Research Part D, Vol.36, p.29(16) (2015)

8. Y. Kayikci, A conceptual model for intermodal freight logistics centre location decisions, Procedia Social and Behavioral Sciences, Vol.2(3), pp.6297$6311(2010)$

9. L. Yang, X. Ji, Z. Gao, K. Li, Logistics distribution centers location problem and algorithm under fuzzy environment, Journal of Computational and Applied Mathematics, Vol.208(2), pp.303-315 (2007)

10. O. Tkach, I. Voloshchuk, Regional logistics center: formation and functioning specific, Aktualnì Problemi Rozvitku Ekonomiki Regìonu, Vol.2(13), pp.127-134 (2013)

11. G. Peng, Z. Yang, Z. Feng, H. Liman, M. Chenhao, Design and implementation of urban logistics distribution center location optimizati on system, Journal of Hebei University of Science and Technology, Vol.38(1), pp.19-2501 (2017)

12. V. Klapita, Z. Švecová, Logistics centers location, Transport, Vol.21(1), p.48-52 (2006)

13. H. Liu, L. Liu, Multi-Objective Location Model Research and Application in the City
Emergency Logistics Based on Different Product Materials, Applied Mechanics and Materials, Vol.6364, p.277 (2011)

14. L. Li, J. Zhang, Logistics Distribution Center Location Optimization Model An Example Study, MATEC Web of Conferences 100, 02026 (2017)

15. H. Xiang, H. Xiao, Y. Wuwei, Research optimization on logistics distribution center location based on adaptive particle swarm algorithm, Optik International Journal for Light and Electron Optics, Vol.127(20), pp.8443-8450 (2016)

16. B. Wang, H. Xiong, Ch. Jiang, A Multicriteria Decision Making Approach Based on Fuzzy Theory and Credibility Mechanism for Logistics Center Location Selection, The Scientific World Journal, Vol.2014 (2014)

17. M. Făgărăhan, C. Ciprian, Logistics center location selection using multicriteria decision making, Annals of the Oradea University: Fascicle Management and Technological Engineering (2015)

18. M. S. Daskin, Network and discrete location: models, algorithms, and applications, John Wiley \& Sons, New York (1995)

19.Z. Drezner, H. Hamacher, Facility Location: Applications and Theory, Springer, Berlin (2002)

20. R. Farahani, M. S. Steadi Seifi, N. Asgari, Multiple criteria facility location problems: A survey. "Applied Mathematical Modelling”, 34, 1689-1709 (2010)

21. R. Farahani, M. Hekmatfar, (Eds.) Facility Location: Concepts, Models, Algorithms and Case Studies, Heidelberg, Physica-Verlag (2009)

22. S. Owen, M. Daskin, Strategic facility location: A review, European Journal of Operational Research, 111, 423 - 447 (1998)

23. T. Özcan, N. Celebi, S. Esnaf, Comparative analysis of multi-criteria decision making methodologies and implementation of a warehouse location selection problem, Expert Systems with Applications, Vol. 38, pp. 9773 - 9779 (2011)

24. V. Van Thai, D. Grewal, Selecting the Location of Distribution Centre in Logistics Operations: A Conceptual Framework and Case Study, Asia Pacific Journal of Marketing and Logistics, Vol. 17, No. 3, pp. 3-24 (2005)

25. A. Rushton, P. Croucher, P. Baker, The Handbook of Logistics and Distribution Management. Third ed., Kogan Page, London, (2006)

26. A. Weber, Theory of the location of industries. University of Chicago Press, pp. 41-42 (1929)

27. K. Brenke, How East German Companies Estimate Location Conditions in Their Region - Survey Results (Wie ostdeutsche Unternehmen die Standortbedingungen in ihrer Region einschätzen Ergebnisse einer Umfrage) Deutsches Institut für Wirtschaftsforschung, Berlin (2003)

28. J. T. Mentzer, 7 keys to facility location, "Supply Chain Management Review" Vol. 12, Iss. 5, pp. 2531 (2008)

29. L. Mindur, Methodology of locating and shaping logistic centers in Poland (Metodyka lokalizacji $i$ ksztaltowania centrów logistycznych w Polsce). Kolejowa Oficyna Wydawnicza, Warszawa (2000 
30. A. Klose, A. Drexl, Facility location models for distribution system design, European Journal of Operational Research, 162, 1, 4-29 (2005)

31. R. Ballou, Business Logistics: Supply Chain Management, 5th edition. Pearson Education, p. 551 (2004)

32. I. A. Kaysi, M. A. Abdul-Malak, Decision Structuring and Robustness Analysis in Selecting Urban Transit Alternatives; Journal of Public Transportation 4(1), 73-102 (2001)

33. T.L. Saaty, Fundamentals of the Analytic Network Process. Multiple Networks with Benefits, Costs, Opportunities and Risks, Journal of Systems Science and Systems Engineering, published at Tsinghua University, Beijing, (to be published) 2004, Vol. 13, No. 3, September (2004)

34. W. Chmielorz, M. Zborowski, The use of the AHP / ANP method in the confrontational method of model design of information systems, (Wykorzystanie metody AHP/ANP w konfrontacyjnej metodzie projektowania wzorcowego systemów informatycznych), Economic IT (Informatyka Ekonomiczna), 2014, Issue 31, pp.195-211 (2014)

35. R. Banai, Fuzziness in Geographical Information Systems: contributions from the Analytic Hierarchy Process, International Journal of Geographical Information Systems. 7, 4, pp. 315- 329 (1993)

36. J. Żak, Multi-criteria decision support in road transport (Wielokryterialne wspomaganie decyzji $w$ transporcie drogowym). Poznań: Wydawnictwo Politechniki Poznańskiej (2005)

37. K. G. Zografos, Analytic Hierarchy Process (AHP): It's application in FTS business model assessment, Athens University of Economics and Business Transportation Systems and Logistics Laboratory. Conference Proceedings, Cremona (2005)

38. K. G. Zografos, K.N Androutsopoulos, A Decision Support System for Integrated Hazardous Materials Routing and Emergency Response Decisions, Transportation Research Part C, Vol. 16(6), pp. 684703. (2008)

39. M. Bouzon, K. Govindan, R. C. Taboada, L. M. S. Campos, Identification and analysis of reverse logistics barriers using fuzzy Delphi method and AHP, Resources, Conservation \& Recycling, March-April 2016, Vol.108, pp.182-197 (2016)
40. Ch. Prakash, M. K. Paura, Integration of AHPTOPSIS method for prioritizing the solutions of reverse logistics adoption to overcome its barriers under fuzzy environment, Journal of Manufacturing Systems, October 2015, Vol.37, pp.599-615 (2015)

41. M. Berrittella, A. Certa, M. Enea, P. Zito, An Analytic hierarchy process for the evaluation of transport policies to reduce climate change impacts http://www.feem.it/Feem/Pub

/Publications/WPapers/default.htm, january 2007.

42. M. Brunnelli, Introduction to the Analytic Hierarchy Proces, Springer (2015)

43. L. G. Vargas, An overview of the Analytic Hierarchy Process and its applications, European Journal of Operational Research, Vol. 48, 2-8 (1990)

44. T. L. Saaty, The Analytic Hierarchy Process, McGraw-Hill, New York (1980)

45. W. J. Hurley, The analytic hierarchy process: a note on an approach to sensitivity which preserves rank order, Computers \& Operations Research, Vol. 28, 185-188 (2001)

46. Y. Li, X. Liu, Y. Chen, Selection of logistics center location using Axiomatic Fuzzy Set and TOPSIS methodology in logistics management, Expert Systems With Applications, June, Vol.38(6), pp.7901-7908 (2011)

47. J. Perez, Some Comments on Saaty's AHP, Management Science, 1995, Vol.41(6), p.1091-1095 (1995)

48. T. L. Saaty, Decision making for leaders; The Analytic Hierarchy Process for decisions in a complex world, RWS Publications, Pittsburgh, (2001)

49. T. L. Saaty, The Analytic Hierarchy Process, RWS Publications, Pittsburgh, (1998)

50. T. L. Saaty, Decision making with Dependence and Feedback: The Analtic Network Process, RWS Publications, Pittsburgh, P.A. (2001)

51. M. Andriejova, Z. Kimakova, D. Marasova, Using ahp method at the determination of the optimal selection criteria of conveyor belts, Annals of the Faculty of Engineering Hunedoara, 2013, Vol.11(2), pp.155-160 (2013)

52. D. Božanić, D. Pamučar, S. Karović, Use of the fuzzy AHP - MABAC hybrid model in ranking potential locations for preparing laying-up positions , Vojnotehnički Glasnik, 01 July 2016, Vol.64(3), pp.705-729 (2016) 